\title{
Microbiological and basic agrochemical properties of Eutric Cambisols in western and south- western Serbia
}

\author{
Nataša Rasulić ${ }^{*}$, Dušica Delić ${ }^{1}$, Olivera Stajković-Srbinović ${ }^{1}$, Aneta Buntić ${ }^{1}$, Đorđe Kuzmanović ${ }^{1}$, \\ Magdalena Knežević ${ }^{1}$, Biljana Sikirić ${ }^{1}$ \\ ${ }^{1}$ Institute of Soil Science, Teodora Drajzera 7, 11000 Belgrade, Serbia \\ ${ }^{*}$ Corresponding author: Nataša Rasulić, nrasulic@yahoo.com
}

\begin{abstract}
One of the most common soil types in area of western and south-western Serbia is the Eutric Cambisol. In order to determine biogenity of this soil type, the presence of total microflora, fungi, actinomycetes, ammonifiers, Azotobacter sp. and oligonitrophils, as well as dehydrogenase activity were examined. Samples were taken from soils used in two different ways (plough fields and meadows). Standard microbiological methods of inoculation a certain decimal dilution on appropriate nutrient media were used. No correlation between the number of microorganisms and type of the soil usage was found. In localities that were under plough fields and meadows, the presence of Azotobacter sp. was confirmed, as an indicator of soil fertility. The correlation of dehydrogenase activity with the total number of microorganisms was not observed. Agrochemical analysis showed acidic to weakly acidic soil reaction, medium to high percentage of organic matter, low content of easily available phosphorus and high content of easily available potassium. There was no correlation between chemical properties of the soil and the number of microorganisms in examined soil type.
\end{abstract}

Keywords: soil biogenity, Eutric Cambisol, microflora

\section{Introduction}

Soil microorganisms actively participate in processes of organic material decomposition, organic matter synthesis and production of easily available assimilates, therefore they represent the most important biological soil component (Milošević et al., 2003). Some bacterial genera and species have been used in soil bioremediation due to their tolerance to pesticides and heavy metals (Ajmal et al., 2021; Verma et al., 2016). In addition, rhizosphere bacteria can colonize plants root and promote plant growth (PGP) by facilitating the absorption of certain nutrients from the soil, synthesizing certain substances useful for plants (Glick,1995), and by protecting plants from diseases (Zahir et al., 2004; Cakmakci et al., 2006). Specific groups of microorganisms are used as indicators of general microbiological activity and potential soil fertility (Tintor et al., 2009). For example, a low number of nitrogen-fixing bacteria indicates a decrease of soil biogenity and thus soil fertility (Milošević, 2008). Each soil type has a specific microbiocenosis and the type of soil usage can have positive or negative effect on microbiological activity, which affects soil 
fertility (Marinković et al., 2018). The term Eutric Cambisol refers to a high degree of base saturation soils (Antić et al., 1990) that are widespread in the western and south-western of Serbia on slightly wavy, hilly terrains at an altitude of 200-600 m (Antić et al., 1990). Physicochemical characteristic of the soil were determined as the most important feature which affects the number and activity of microorganisms (Milošević et al., 2007; Marinković et al., 2008). Eutric Cambisol soils are predominantly loamy, with slightly increased content of clay in the (B) horizon and favourable physical properties, such as good drainage and favourable air regime (Ćirić, 1991). Regarding the chemical performances, they vary a lot. Biological activity of these soils is highly diverse, as soil $\mathrm{pH}$ varies from acidic to neutral, which in some cases can be beneficial (Antić et al., 1990).

The aim of this research was to determine the correlation between the number of microorganisms and soil exploitation type, as well as to determine the basic agrochemical properties of the examined soil type. The 26 localities from western and south-western area of Serbia were selected. Dehydrogenase activity and the presence of different groups of microorganisms (total microflora, fungi, actinomycetes, Azotobacter sp., free nitrogen fixators) in collected soil samples were analyzed in order to observe the general soil biogenity and fertility.

\section{Materials and Methods}

From the area of western and south-western Serbia, 26 localities were chosen: 19 plough fields and 7 meadows. As the number and enzymatic activity of microorganisms is the highest in the surface soil layer, (Marinković et al., 2008), soil samples were taken aseptically from a depth of 0-30 cm for microbiological and agrochemical analysis.

The basic parameters for assessing soil biogenity were: total microflora, total number of fungi, actinomycetes, ammonifiers, Azotobacter sp. and oligonitrophils, as well as the soil dehyrogenase activity. The number of microorganisms was determined by standard microbiological methods by inoculating a certain amount of soil suspension on appropriate nutrient media using decimal dilutions $\left(10^{-1}-10^{-8}\right)$ (Pochon and Tardieux, 1962). Total microflora was determined on agar soil extract (Sarić, 1989), fungi on Chapek media (Sarić, 1989), actinomycetes on synthetic agar with sucrose according to Krasiljnikov (Govedarica and Jarak, 1996), ammonifiers in a liquid media with asparagine as a nitrogen source (Vojinović et al, 1966), Azotobacter sp. in a liquid nitrogen-free media according to Chan (Vojinović et al, 1966) and oligonitrophils on a nitrogen-free media according to Fjodorov (Sarić, Z., 1989). Soil dehydrogenase activity was determined by Lenhard's method (1956), modified by Thalman (1968), which is based on measuring the extinction of triphenolformazon (TPF) formed by the reduction of 2,3,5-triphenyltetrazolium chloride. 
The $\mathrm{pH}$ of soil was determined by $\mathrm{pH}$ meter (in 1M KCl) according to SRPS ISO 10390. The content of soil organic matter was determined according to SRPS ISO 10694. Available P and K in the soil samples were determined by the Al-method (Riehm, 1958). The $0.1 \mathrm{~mol} \mathrm{~L}^{-1}$ ammonium lactate $(\mathrm{pH}=3.7)$ was used as an extract. After extraction, $\mathrm{K}_{2} \mathrm{O}$ was determined by a flame emission photometry and $\mathrm{P}_{2} \mathrm{O}_{5}$ by spectrophotometer after color development with ammonium molybdate and $\mathrm{SnCl}_{2}$.

\section{Results and Discussions}

Results of basic agrochemical analyses of the examined Eutric Cambisol soils are shown in Table 1. The reaction of examined soil was uneven and ranged from acidic to neutral. However, most samples had acidic to weakly acidic reaction, which is unfavourable for the growth and activity of majority of soil microorganisms. It has been known that soil $\mathrm{pH}$ directly affects the mobility of nutrients by altering their accessibility for plants and the composition of soils microbial population (Tintor et al., 2009).

Table 1. Basic agrochemical properties of the examined Eutric Cambisol soils

\begin{tabular}{cccccc}
\hline Type of soil usage & Location & $\mathrm{pH}(\mathrm{KCl})$ & Organic matter, $\%$ & $\mathrm{P}_{2} \mathrm{O}_{5}, \mathrm{mg} 10^{-2} \mathrm{~g}^{-1}$ & $\mathrm{~K}_{2} \mathrm{O}, \mathrm{mg} 10^{-2} \mathrm{~g}^{-1}$ \\
\hline & 1 & 3.90 & 4.28 & 5.46 & 26.00 \\
& 2 & 6.15 & 4.60 & 5.60 & 19.40 \\
& 3 & 5.35 & 4.45 & 5.33 & 30.40 \\
$\mathrm{P}$ & 4 & 5.15 & 3.27 & 3.68 & 23.20 \\
$\mathrm{~L}$ & 5 & 5.50 & 4.31 & 1.37 & 32.00 \\
$\mathrm{O}$ & 6 & 5.80 & 4.25 & 20.64 & 40.00 \\
$\mathrm{U}$ & 7 & 5.50 & 5.43 & 10.38 & 40.00 \\
$\mathrm{G}$ & 8 & 6.50 & 5.49 & 40.80 & 40.00 \\
$\mathrm{H}$ & 9 & 5.00 & 3.20 & 0.95 & 11.60 \\
& 10 & 4.60 & 3.23 & 3.87 & 12.60 \\
$\mathrm{~F}$ & 11 & 4.70 & 4.59 & 6.24 & 31.60 \\
$\mathrm{I}$ & 12 & 5.70 & 5.40 & 7.17 & 36.00 \\
$\mathrm{E}$ & 13 & 5.80 & 4.80 & 2.99 & 40.00 \\
$\mathrm{~L}$ & 14 & 6.25 & 1.00 & 11.76 & 28.30 \\
$\mathrm{D}$ & 15 & 5.50 & 4.41 & 6.08 & 26.00 \\
& 16 & 5.40 & 4.61 & 15.83 & 23.00 \\
& 17 & 5.65 & 3.79 & 8.16 & 32.00 \\
& 18 & 6.80 & 4.44 & 3.00 & 40.00 \\
& 19 & 4.60 & 3.92 & 10.67 & 40.00 \\
\hline $\mathrm{M}$ & 1 & 5.40 & 3.74 & 1.69 & 24.00 \\
$\mathrm{E}$ & 2 & 5.50 & 4.68 & 2.22 & 11.00 \\
$\mathrm{~A}$ & 3 & 5.35 & 4.35 & 5.51 & 28.00 \\
$\mathrm{D}$ & 4 & 5.30 & 7.19 & 5.75 & 29.60 \\
$\mathrm{O}$ & 5 & 5.65 & 6.10 & 5.48 & 40.00 \\
$\mathrm{~W}$ & 6 & 5.00 & 5.68 & 3.26 & 39.50 \\
& 7 & 6.10 & 4.09 & 6.46 & 40.00 \\
\hline
\end{tabular}


As for the content of organic matter, the majority of samples showed medium to high percentage of organic matter. The content of soil organic matter is important for the activity of the soil microflora, as a source of necessary energy. The content of easily available phosphorus varied a lot, which is in accordance with literature data. The majority of samples showed low content of easily available phosphorus, while in the most cases the content of easily available potassium ranged from high to very high.

The values of total microflora in the tested samples were low to medium high, with the exception of locality 7 (meadow), which showed a slightly higher organic matter content and favourable $\mathrm{pH}$ (Table 2). The inequality in the number of microorganisms (ranging from $2.33 \times 10^{6} \mathrm{~g}^{-1}$ to $42.33 \times 10^{6} \mathrm{~g}^{-1}$ ) showed characteristically high dynamics in relatively short period of time, indicating that the number of microorganisms could drastically change as the effect of soil temperature dynamics and humidity, as well as vegetation cover (Jemcev and Đukić, 2000).

Actinomycetes, as important transformers of organic matter in soil, were poorly represented, with the exception of localities 2, 7, 11, 1216 (plough field), as well as the locality 5 (meadow). Values ranged from $0.33 \times 10^{4} \mathrm{~g}^{-1}$ to $36.67 \times 10^{4} \mathrm{~g}^{-1}$ and no correlation with $\mathrm{pH}$ and organic matter content was observed.

In addition, the number of fungi (one of the essential decomposers of organic matter in the soil) was higher than the number of actinomycetes, with values ranging from $4.67 \times 10^{4} \mathrm{~g}^{-1}$ to $22.67 \times 10^{4} \mathrm{~g}^{-1}$. Similarly to the actinomycetes, a high variation of the number of fungi was observed, while no correlation was found with $\mathrm{pH}$ and organic matter content. Fungi as acidophilic microorganisms showed no higher representation in samples with lower $\mathrm{pH}$.

Ammonifiers, as the users of organic nitrogen and protein decomposers, are one of the most common microorganisms groups in the soil. Their number in the chernozem soil type can reach values from $10^{7} \mathrm{~g}^{-1}$ to $10^{9} \mathrm{~g}^{-1}$ (Marinković et al., 2018). In examined Eutric Cambisol soil samples their number highly varied in a range from $0.4 \times 10^{5} \mathrm{~g}^{-1}$ to $450.00 \times 10^{5} \mathrm{~g}^{-1}$, and was not correlated with the content of organic matter.

Azotobacter sp. (atmospheric nitrogen fixator and soil fertility indicator) showed weak representation in examined plough field samples with the exception of locality 12, while in the localities under meadow in most samples its presence was not recorded. The research conducted by Govedarica et al. (2000), showed that Azotobacter sp. in plough fields could reach the number of $10^{3} \mathrm{~g}^{-1}$, which leads us to conclude that examined Eutric Cambisol soils did not provide optimal conditions for the activity of Azotobacter sp., despite the favourable chemical properties. 
Table 2. Microbiological properties of the examined Eutric Cambisol soils

\begin{tabular}{|c|c|c|c|c|c|c|c|c|}
\hline $\begin{array}{c}\text { Typ } \\
\text { e of } \\
\text { soil } \\
\text { usag } \\
\text { e }\end{array}$ & $\begin{array}{c}\text { Locatio } \\
n\end{array}$ & $\begin{array}{c}\text { Total } \\
\text { microflo } \\
\text { ra } \\
\left(\times 10^{6}\right)\end{array}$ & $\begin{array}{c}\text { Actinomycet } \\
\text { es } \\
\left(\times 10^{4}\right)\end{array}$ & $\begin{array}{l}\text { Fung } \\
\mathrm{i} \\
\left(\times 10^{4}\right)\end{array}$ & $\begin{array}{c}\text { Ammonifie } \\
\text { rs } \\
\left(\times 10^{5}\right)\end{array}$ & $\begin{array}{c}\text { Azotobact } \\
\text { er } \\
\text { sp. } \\
\text { MPN }\end{array}$ & $\begin{array}{c}\text { Oligonitrophil } \\
\text { ers } \\
\left(\times 10^{5}\right)\end{array}$ & $\begin{array}{c}\text { Dehydrogena } \\
\text { se } \\
\text { activity, } \\
\mu \mathrm{gTPF} \mathrm{g}^{-1}\end{array}$ \\
\hline \multirow{11}{*}{$\begin{array}{l}\mathrm{P} \\
\mathrm{L} \\
\mathrm{O} \\
\mathrm{U} \\
\mathrm{G} \\
\mathrm{H}\end{array}$} & 1 & 6.00 & 2.33 & $\begin{array}{c}17.6 \\
7\end{array}$ & 2.00 & 9 & 17.67 & 34.67 \\
\hline & 2 & 15.33 & 13.33 & $\begin{array}{c}22.6 \\
7\end{array}$ & 3.00 & 9 & 51.67 & 9.31 \\
\hline & 3 & 13.33 & 5.33 & $\begin{array}{c}22.6 \\
7\end{array}$ & 45.00 & 15 & 74.00 & 38.45 \\
\hline & 4 & 14.67 & 5.67 & $\begin{array}{c}15.0 \\
0\end{array}$ & 250.00 & 9 & 66.00 & 527.29 \\
\hline & 5 & 11.00 & 7.33 & $\begin{array}{c}12.6 \\
7\end{array}$ & 9.50 & 4 & 50.33 & 175.06 \\
\hline & 6 & 10.00 & 2.67 & 8.33 & 2.50 & 95 & 55.67 & 13.14 \\
\hline & 7 & 13.00 & 18.00 & 8.33 & 9.5 & 45 & 108.00 & 158.54 \\
\hline & 8 & 11.33 & 4.33 & 7.33 & 1.00 & 25 & 60.67 & 211.17 \\
\hline & 9 & 2.33 & 2.33 & $\begin{array}{c}10.0 \\
0\end{array}$ & 25.00 & 9 & 24.67 & 140.33 \\
\hline & 10 & 14.67 & 7.00 & $\begin{array}{c}16.6 \\
7\end{array}$ & 150.00 & 4 & 44.33 & 48.49 \\
\hline & 11 & 6.00 & 13.67 & $\begin{array}{c}11.0 \\
0\end{array}$ & 4.50 & 0 & 59.67 & 0.59 \\
\hline \multirow{8}{*}{$\begin{array}{l}\text { F } \\
\text { I } \\
\text { E } \\
\text { L } \\
\text { D }\end{array}$} & 12 & 16.33 & 15.67 & $\begin{array}{c}10.6 \\
7\end{array}$ & 7.50 & 250 & 43.67 & 45.53 \\
\hline & 13 & 4.33 & 2.00 & $\begin{array}{c}12.3 \\
3\end{array}$ & 0.4 & 0 & 6.00 & 87.98 \\
\hline & 14 & 14.33 & 1.00 & $\begin{array}{c}11.6 \\
7\end{array}$ & 450.00 & 0 & 66.00 & 296.96 \\
\hline & 15 & 17.67 & 13.00 & $\begin{array}{c}16.3 \\
3\end{array}$ & 45.00 & 0 & 89.00 & 93.73 \\
\hline & 16 & 7.67 & 2.00 & $\begin{array}{c}19.0 \\
0\end{array}$ & 4.50 & 0 & 44.00 & 38.42 \\
\hline & 17 & 10.00 & 5.33 & 9.67 & 45.00 & 4 & 31.33 & 136.53 \\
\hline & 18 & 26.33 & 8.33 & 4.67 & 1.50 & 25 & 70.67 & 42.26 \\
\hline & 19 & 10.33 & 6.00 & $\begin{array}{c}20.6 \\
7\end{array}$ & 2.0 & 25 & 37.33 & 41.16 \\
\hline \multirow{7}{*}{$\begin{array}{c}\text { M } \\
\text { E } \\
\text { A } \\
\text { D } \\
\text { O } \\
\text { W }\end{array}$} & 1 & 10.67 & 7.33 & 8.67 & 4.50 & 25 & 41.00 & 626.26 \\
\hline & 2 & 4.33 & 1.67 & $\begin{array}{c}11.0 \\
0\end{array}$ & 0.40 & 0 & 13.00 & 58.23 \\
\hline & 3 & 8.00 & 7.00 & $\begin{array}{c}13.6 \\
7\end{array}$ & 7.50 & 0 & 50.67 & 39.42 \\
\hline & 4 & 12.33 & 7.67 & 6.67 & 45.00 & 0 & 55.33 & 230.75 \\
\hline & 5 & 15.33 & 36.67 & $\begin{array}{c}16.3 \\
3\end{array}$ & 45.00 & 4 & 60.33 & 153.57 \\
\hline & 6 & 8.33 & 0.33 & $\begin{array}{c}14.6 \\
7\end{array}$ & 2.50 & 0 & 19.33 & 33.21 \\
\hline & 7 & 42.33 & 9.00 & 22.3 & 7.50 & 45 & 141.66 & 653.04 \\
\hline
\end{tabular}

Number of microorganisms was calculated per gram of dry soil. MPN: most probable number. 
Oligonitrophiles represented a dominant physiological group of microorganisms, which could indicate an unfavourable nitrogen regime of the examined soils. The content of oligonitrophiles in examined plough field was uneven and varied from $6.00 \times 10^{5} \mathrm{~g}^{-1}$ to $108.00 \times 10^{5} \mathrm{~g}^{-1}$, while in meadow samples their values varied from $13.00 \times 10^{5} \mathrm{~g}^{-1}$ to $141.67 \times 10^{5} \mathrm{~g}^{-1}$.

Establishing the activity of the enzyme participating in mineralization of the organic substance in soil is an indicator of the soil biological activity. One of these enzymes is oxydoreducing enzyme of dehydrogenase (Meena and Rao, 2021). Dehydrogenase activity may be considered as a good measure for microbial oxidative activity in soil (Bolton et al, 1984). Regarding dehydrogenase activity, it varied from $0.59 \mu \mathrm{gTPF} \mathrm{g}^{-1}$ to $653.04 \mu \mathrm{gTPF} \mathrm{g}^{-1}$ in the examined samples and correlation with the number of microorganisms was not found. Similar variations of dehidrogenase activity were observed in a research conducted by Wolińska et al. (2015). Furthermore, no difference in dehydrogenase activity between plough field samples and meadow samples was observed.

\section{Conclusion}

Despite relatively favourable agrochemical properties, Eutric cambisols in the western and south-western area of Serbia did not show great biogenity. In the most cases, the number of physiological microorganisms group was uneven and mostly low, with the exception of fungi and oligonitrophils. A particularly low number of ammonifiers, which represent the most common microorganisms group in the soil, was observed. Azotobacter sp., as an indicator of soil fertility was also poorly represented. No difference between the examined localities under plough fields and under meadows was noticed.

Acknowledgment: This research was supported by the Ministry of Education, Science and Technological Development of the Republic of Serbia (contract No. 451-03-9/2021-14/200011).

\section{References}

Ajmal A, Saroosh S, Mulk S, Hassan M, Yasmin H, Jabeen Z, Nosheen A, Shah S, Naz R, Hasnain Z, Qureshi T, Waheed A, Mumtaz S. 2021: Bacteria Isolated from Wastewater Irrigated Agricultural Soils Adapt to Heavy Metal Toxicity While Maintaining Their Plant Growth Promoting Traits. Sustainability, 13(14): 7792.

Antić M, Jović N, Avdalović V. 1990: Pedologija, Naučna knjiga, Beograd.

Bolton Jr H, Elliott LF, Papendick RI, Bezdicek DF. 1984: Soil Microbial biomass and selected soil enzyme activities: Effect of fertilization and cropping practices. Soil Biology\& Biochemistry, 17: 297-302. 
Cakmakci RI, Aydin DF, Sachin AF.2006: Growth promotion of plants by plant growth-promoting rhizobacteria under greenhouse and two different field soil conditions. Soil Biology \& Biochemistry, 38:1482-1487.

Ćirić M. 1991: Pedologija, „Svjetlost“, Sarajevo.

Glick BR.1995: The enhancement of plant growth by free living bacteria. Canadian Journal of Microbiology, 41:109-11.

Govedarica M, Milošević N, Jarak M, Đurić S, Milošević D,Konstatinović B. 2000: Uticaj herbicida na mikrobiološku aktivnost u zemljištu pod usevom pšenice. EKO-konferencija 2000. Zdravstveno bezbedna hrana, Tematski zbornik, II: 25-30.

Govedarica M, JarakM. 1996: Praktikum iz mikrobiologije, Poljoprivredni fakultet, Novi Sad.

Jemcev V, Đukić D. 2000: Mikrobiologija, Vojnoizdavački zavod, Beograd.

Marinković J, Bjelić D, Ninkov J, Vasin J, Tintor B, Živanov M. 2018: Efekat različitih načina korišćenja zemljišta Centralne Srbije, Ratarstvo i povrtarstvo,55 (2): 58-64.

Marinković J, Bjelić D, Šeremešić S, Tintor B, Ninkov J, Živanov M, Vasin J.2018: Brojnost i aktivnost mikroorganizama u černozemu pri različitim sistemima gajenja, Ratarstvo i povrtarstvo, 55 (1): 6-11

Marinković J, Milošević N, TintorB, Sekulić P, Nešić Lj.2008: Mikrobiološka svojstva fluvisola na različitim lokalitetima u okolini Novog Sada, Ratarstvo i povrtarstvo, 45(2): 215-223.

Meena A, Rao K. 2021: Assessment of soil microbial and enzyme activity in the rhizosphere zone under different land use/cover of a semiarid region, India. Ecological Processes, 10 (1).

Milošević N, Tintor B, Dozet D, Cvijanović G. 2007: Mikrobiološka svojstva zemljišta prirodnih travnjaka, Ratarstvo i povrtarstvo,44 (4):541-546.

Milošević N, Ubavić M, Čuvardić M, Vojin S. 2003: Mikrobi-značajno svojstvo za karakterizaciju plodnosti poljoprivrednog zemljišta. Agroznanje, Banja Luka, God IV(2): 81-88.

Milošević N. 2008: Mikroorganizmi-bioindikatori zdravlja/kvaliteta zemljišta, Ratarstvo i povrtarstvo, 45(1): 205-215.

Pochon J, Tardieux P. 1962: Tehnikues danalise en microbiologique du Soil edit de la tourel, Paris

Rhiem H. 1958: Die ammoniumlaktatessigsaure-Methode zur Bestimmung der leichtloslichen Phosphorsure in Karbonathaltigen Boden. Agrochimica 3:49-65.

Sarić Z. 1989: Praktikum iz mikrobiologije, Naučna knjiga,Beograd.

SRPS ISO 10390:2007 Soil Quality-Determination of pH; SRPS, Institute for Standardisation of Republic of Serbia: Belgrade, Serbia, 2007.

SRPS ISO 10694:2005 Soil Quality-Determination of Organic and Total Carbon after Dry Combustion [Elementary Analysis]; SRPS, Institute for Standardisation of Republic of Serbia: Belgrade, Serbia, 2005 . 
Stamenov D, Đurić S, Hajnal-Jafari T, Šeremešić S. 2016: Uticaj đubrenja i plodoreda na brojnost mikroorganizama u zemljištu, Ratarstvo i povrtarstvo, 53(3): 96-100.

Thalmann A. 1968: Zur Methodil des Bestimmung der Dehidrogenase Activat in Boden Mittles Tripheyltetrazoliumhlorid TTC, London Forch 21: 249-258.

Tintor B, Milošević N, Vasin J. 2009: Mikrobiološka svojstva černozema južne Bačke u zavisnosti od načina korišćenja zemljišta, Ratarstvo i povrtarstvo, 46(1): 189-198.

Verma JP, Jaiswal DK, Maurya PK. 2016: Screening of bacterial strains for developing effective pesticidetolerant plant growth-promoting microbial consortia from rhizosphere soils of vegetable fields of eastern Uttar Pradesh, India. Energy, Ecology and Environment 1: 408-418.

Vojinović Ž, Prša M, Petrović V, Sarić Z, Todorović M. 1966: Određivanje fizioloških grupa mikroorganizama i biološke sposobnosti zemljišta, Priručnik za ispitivanje zemljišta JDPZ,Knjiga II, Mikrobiološke metode ispitivanja zemljišta ivoda: 32-41.

Wolińska A, Rekosz-Burlaga H, Goryluk-Salmonowicz A, Błaszczyk M, Stępniewska Z. 2015: Bacterial Abundance and Dehydrogenase Activity in Selected Agricultural Soils from Lublin Region. Polish Journal of Environmental Studies, 24(6): 2677-2682.

Zahir ZA, Arshad M, Frankenberger WT. 2004: Plant growth promoting rhizobia: applications and perspectives in agriculture. Advances in Agronomy, 81:97-168. 


\title{
Mikrobiološke i osnovne agrohemijske osobine eutričnih kambisola na području zapadne i jugozapadne Srbije
}

\author{
Nataša Rasulić ${ }^{*}$, Dušica Delić ${ }^{1}$, Olivera Stajković-Srbinović ${ }^{1}$, Aneta Buntić ${ }^{1}$, Đorđe Kuzmanović ${ }^{1}$, \\ Magdalena Knežević ${ }^{1}$, Biljana Sikirić ${ }^{1}$ \\ ${ }^{1}$ Institut za zemljište, Teodora Drajzera 7, 11000 Beograd, Srbija \\ ${ }^{*}$ Corresponding author: Nataša Rasulić, nrasulic@yahoo.com
}

\section{IZVOD}

Jedan od najzastupljenijih tipova zemljišta u brdsko-planinskom području zapadne i jugozapadne Srbije je eutrični kambisol. U cilju utvrđivanja biogenosti ovog tipa zemljišta, ispitana je zastupljenost ukupne mikroflore, gljivica, aktinomiceta, amonifikatora, Azotobacter sp. i oligonitrofila, kao i dehidrogenazna aktivnost navedenog tipa zemljišta. Uzorci su uzeti iz zemljišta korišćenih na dva različita načina (oranice i livade). Korišćene su standardne mikrobiološke metode zasejavanja određenog decimalnog razređenja na odgovarajuće hranljive podloge. Nije ustanovljena korelacija između broja grupa mikroorganizama i načina korišćenja zemljišta. Utvrđena je mala zastupljenost Azotobacter sp., kao indikatora plodnosti zemljišta, u lokalitetima pod livadom. Nije konstatovana korelacija dehidrogenazne aktivnosti analiziranih uzoraka sa ukupnim brojem mikroorganizama. Agrohemijske analize su pokazale kiselu do slabo kiselu reakciju, srednji do visok procenat organske materije, nizak sadržaj lako pristupačnog fosfora i visok sadržaj lako pristupačnog kalijuma. Nisu ustanovljene korelacije između hemijskih osobina zemljišta i ukupnog broja mikroorganizama.

Ključne reči: biogenost zemljišta, eutrični kambisoli, mikroflora

Received 09.09.2021

Revised 16.09.2021

Accepted 30.09.2021 